\title{
Sclerostin Measurement
}

National Cancer Institute

\section{Source}

National Cancer Institute. Sclerostin Measurement. NCI Thesaurus. Code C117857.

The determination of the amount of sclerostin present in a sample. 